\title{
KEMAMPUAN MEMBACA DATA DAN RASA INGIN TAHU SISWA TERHADAP KEMAMPUAN LITERASI STATISTIK
}

\author{
Nurokhmi Wahyu Setiani ${ }^{1}$, Amin Suyitno ${ }^{1}$ \\ ${ }^{1}$ Universitas Negeri Semarang \\ *Corresponding email: nurokhmi17@gmail.com
}

Naskah diterima: 22 Juli 2021| Disetujui: 19 Agustus2021 | Diterbitkan: 21 Agustus 2021

\begin{abstract}
Statistical literacy skills are the skills students need in the face of education in the $21^{\text {st }}$ century. Factors that can affect statistical literacy skills include curiosity and read data. However, statistical literacy skills in learning in schools are still low, so this study aims to analyze students' statistical literacy skills based on reading data skills and curiosity. Where reading data is a basic ability in literacy and curiosity is one of the important factors that can affect students' abilities. This study uses qualitative descriptive research design. The research was conducted at SMK Komputama Jeruklegi. The subject was based on the results of a curiosity questionnaire of students and a statistical literacy test. The results of the study obtained that from each curiosity category will bring up indicators of statistical literacy skills that vary. Students of very high curiosity category can bring up all statistical literacy indicators. Students of high and medium categories can bring up statistical literacy indicators such as understanding data, calculating data, presenting data, and drawing conclusions from the data. Lastly, students of the low curiosity category still need help with almost all statistical literacy skills indicators.
\end{abstract}

Keywords: curiosity; read data; statistical literacy

\begin{abstract}
Abstrak: Kemampuan literasi statistik merupakan kemampuan yang dibutuhkan siswa dalam menghadapi pendidikan di abad-21. Faktor yang dapat mempengaruhi kemampuan literasi statistik antara lain rasa ingin tahu dan kemampuan membaca data. Namun begitu, kemampuan literasi statistik dalam pembelajaran di sekolah masih rendah, sehingga penelitian ini bertujuan untuk menganalisis kemampuan literasi statistik siswa berdasarkan kemampuan membaca data serta rasa ingin tahu. Di mana membaca data merupakan kemampuan dasar dalam literasi dan rasa ingin tahu merupakan salah satu faktor penting yang dapat mempengaruhi kemampuan siswa. Penelitian ini menggunakan desain penelitian deskriptif kualitatif. Penelitian dilaksanakan di SMK Komputama Jeruklegi. Pengambilan subjek berdasarkan hasil angket curiosity siswa dan tes literasi statistik. Hasil penelitian diperoleh bahwa dari masing-masing kategori rasa ingin tahu akan memunculkan indikator kemampuan literasi statistik yang berbeda-beda. Siswa kategori curiosity sangat tinggi dapat memunculkan semua indikator literasi statistik. Siswa kategori curiosity tinggi dan sedang dapat memunculkan indikator literasi statistik antara lain memahami data, menghitung data, menyajikan data, serta menarik kesimpulan dari data. Terakhir, siswa kategori curiosity rendah masih membutuhkan bantuan hampir di seluruh indikator kemampuan literasi statistik.
\end{abstract}

Kata kunci: rasa ingin tahu; membaca data; literasi statistik 


\section{PENDAHULUAN}

Di era yang serba digital semua informasi dengan mudah kita dapat melalui internet, media sosial, maupun televisi. Era digital adalah masa ketika informasi mudah dan cepat diperoleh serta disebarluaskan menggunakan teknologi digital (Kemendikbud, 2018). Jika teknologi digital digunakan secara tepat maka akan memberikan manfaat. Namun jika digunakan berlebihan dapat memberikan risiko yang tidak baik. Artikel atau berita merupakan salah satu informasi yang dapat kita peroleh melalui media digital. Artikel atau berita tersebut sering menyertakan data-data kuantitatif untuk meyakinkan pembacanya. Oleh karena itu, agar dapat memahami informasi secara tepat dibutuhkan suatu kemampuan membaca serta memahami data. Hal tersebut agar seseorang tidak asal dalam mengambil informasi sehingga dapat membantunya dalam memutuskan mana yang harus dipercaya.

Kemampuan untuk menafsirkan dan mengevaluasi informasi serta argumen berbasis data secara kritis dan kemampuan mereka untuk mendiskusikan pendapat mengenai informasi statistik disebut kemampuan literasi statistik (Gal, 2002). Selanjutnya Gal juga menjelaskan bahwa pemahaman dan interpretasi merupakan dua keterampilan membaca dalam literasi statistik. Hal tersebut menunjukkan bahwa siswa harus dapat memahami pesan serta dapat menyajikan pesan sehingga pesan dapat diterima dan tersampaikan dengan efektif dan efisien.

Kenyataannya masih banyak siswa yang kesulitan jika dihadapkan dengan permasalahan data, walaupun sekedar membaca data dengan baik. Hal tersebut dibuktikan dengan hasil wawancara di SMK Komputama Jeruklegi dengan guru mata pelajaran matematika kelas XII yang mengatakan bahwa kebanyakan siswa-siswinya kesulitan mengerjakan soal atau permasalahan yang berbentuk soal cerita. Siswa masih kebingungan dalam menentukan dan memahami hal-hal penting dari bacaan. Namun, ketika ditanya apakah mereka telah memahami bacaan yang diberikan, mereka menjawab paham tetapi mereka tidak dapat memberikan kesimpulan. Bahkan beberapa dari mereka sama sekali tidak dapat menjawab pertanyaan. Guru tersebut juga menambahkan contoh lain permasalahan yang dialami siswanya, seperti saat awal semester siswa diberikan jadwal pelajaran baru yang berbentuk tabel berisi kelas, hari, jam pelajaran ke-, kode guru, dan mata pelajaran. Meskipun jadwal pelajaran sepertinya bukan hal asing tetapi tetap ada siswa yang kesulitan dalam membaca jadwal tersebut dan membutuhkan bantuan agar dapat memahaminya.

Kemampuan membaca data dan rasa ingin tahu (curiosity) dalam menyelesaikan masalah menjadi kemampuan yang penting. Namun begitu kemampuan tersebut masih kurang dimiliki siswa. Padahal membaca data merupakan salah satu dari indikator dasar literasi. Siswa yang dapat membaca data akan mempermudah mereka untuk mencapai indikator-indikator selanjutnya dalam kemampuan 
literasi statistik. Hal tersebut berguna bagi mereka baik untuk memecahkan persoalan sehari-hari maupun persoalan matematika.

Indikator yang dapat digunakan untuk mengukur kemampuan literasi statistik, penalaran statistic, dan berfikir statistik siswa (Delmas, 2002), selengkapnya dapat dilihat pada tabel 1 berikut.

Tabel 1. Typical words associated

with different assessment item or tasks

\begin{tabular}{lll}
\hline Statistical literacy & $\begin{array}{l}\text { Statistical } \\
\text { reasoning }\end{array}$ & $\begin{array}{l}\text { Statistical } \\
\text { thinking }\end{array}$ \\
\hline Identify & Explain why & Critique \\
Describe & Explain how & Evaluate \\
Translate & & Generalize \\
Interpret & & \\
Read & & \\
Compute & & \\
\hline
\end{tabular}

Literasi statistik melibatkan komponen pengetahuan dan disposisi matematik (Gal, 2002). Model yang diusulkan Gal membagi komponen pengetahuan menjadi lima elemen kognitif antara lain keterampilan literasi, pengetahuan statistik, pengetahuan matematika, pengetahuan konteks, dan pertanyaan kritis. Kemudian komponen yang kedua adalah disposisi yang terdiri dari dua elemen antara lain sikap kritis dan keyakinan sikap. Seperti halnya numerasi orang secara keseluruhan, komponen dan elemen dalam model harus dipandang sebagai kumpulan blok penyusun dinamis yang bergantung pada konteks yang bersama-sama aktifkan perilaku melek statistik. Khususnya, pemahaman, interpretasi, dan reaksi terhadap informasi statistik memerlukan dan tidak hanya bergantung pada pengetahuan statistik, tetapi sebanyak ketersediaan keterampilan literasi, pengetahuan matematika, dan dunia konteks khusus dan umum pengetahuan. Namun, evaluasi kritis terhadap informasi statistik (setelah dipahami dan ditafsirkan) juga tergantung pada kemampuan untuk mengakses pertanyaan kritis dan mengaktifkan sikap, yang pada gilirannya didukung oleh seperangkat keyakinan dan sikap.

Hasil penelitian yang mengembangkan kemampuan literasi statistis pada siswa sekolah menengah pertama atau madrasah tsanawiyah (Maryati, 2018) menganalisis terkait literasi statistik berdasarkan indikator-indikator dalam hal a) membaca data statistika, b) memahami konsep statistika, c) mengkomunikasikan proses pengolahan data statistika, dan d) mempresentasikan hasil pengolahan 
data statistika. Dalam konteks penelitian tersebut, siswa membaca data statistika yaitu mampu mencari informasi yang disajikan dalam tampilan. Memahami data statistika yaitu siswa dapat menangkap ide-ide statistika yang dapat dijadikan solusi dalam menyelesaikan permasalahan statistika. Mengkomunikasikan proses pengolahan data statistika yaitu siswa mampu menyampaikan proses pengolahan data statistika secara sistematis, baik dengan lisan maupun tulisan. Mempresentasikan hasil pengolahan data statistika yaitu siswa mampu menyajikan hasil pengolahan data statistika dengan menggunakan cara dan tampilan alternatif. Kemudian, dalam penelitian lainnya menuliskan indikator literasi statistik antara lain menafsirkan data, menuliskan informasi yang diketahui dari data, mengelola data, menarik kesimpulan dari data, dan menyajikan data dalam berbagai cara atau tampilan alternatif (Amalia, 2020). Berdasarkan indikator-indikator di atas, maka indikator literasi statistik yang digunakan dalam penelitian ini adalah memahami data, menghitung data, menafsirkan data, menyajikan data, dan menarik kesimpulan dari data.

Faktor penting yang memengaruhi kemampuan literasi statistik yaitu rasa ingin tahu (curiosity) dan kesadaran yang tinggi terhadap pembelajaran dan kebutuhannya (Nishfani, 2017). Rasa ingin tahu (curiosity) adalah suatu keinginan yang besar dalam diri seseorang dalam mencari jawaban terhadap permasalahan yang diberikan (Zetriuslita, 2016). Dengan rasa ingin tahu yang ditanamkan ke diri siswa dapat mempermudah siswa dalam menyelesaikan suatu masalah. Kemudian Daniel Berlyne (Litman, 2003) meletakkan rasa ingin tahu pada dua sumbu dengan membuat empat dimensi. Salah satu sumbunya terdapat epistemic curiosity yaitu berupa keinginan untuk memperoleh informasi dan pengetahuan, dan perceptual curiosity yang mendeskripsikan bagaimana seseorang menaruh perhatiannya pada suatu hal yang baru di lingkungannya. Di sumbu yang lainnya, terdapat specific-absorption, yaitu berupa keinginan untuk sebuah pengamatan yang spesifik, dan diversiveexploration, yaitu rasa ingin tahu yang mendorong seseorang untuk mencari stimulus agar keluar dari rasa bosan. Dimensi-dimensi tersebut dapat digunakan untuk mengukur rasa ingin tahu (curiosity) siswa. Berdasarkan uraian-uraian di atas, maka peneliti akan menganalisis kemampuan membaca data dan rasa ingin tahu siswa terhadap kemampuan literasi statistik siswa.

\section{METODE}

Metode yang digunakan dalam penelitian ini adalah metode penelitian deskriptif kualitatif yang dilakukan di SMK Komputama Jeruklegi pada tahun ajaran 2020/2021. Subjek yang digunakan dalam penelitian adalah siswa kelas XII TKJ 1 (Teknologi Komputer dan Jaringan) yang berjumlah 22 siswa. Pengambilan subjek penelitian berdasarkan hasil angket rasa ingin tahu (curiosity) siswa dan tes literasi statistik. Kemudian rasa ingin tahu dibagi menjadi lima kategori antara lain kategori 
sangat tinggi, tinggi, sedang, rendah, dan sangat rendah (Belecina, 2016). Pengkategorian dapat dilihat seperti Tabel 2 berikut ini.

Tabel 2. Kategori angket rasa ingin tahu siswa

\begin{tabular}{ll}
\hline Rata-rata & Kategori \\
\hline $4,51-5,00$ & Sangat tinggi \\
$3,51-4,50$ & Tinggi \\
$2,51-3,50$ & Sedang \\
$1,51-2,50$ & Rendah \\
$1,00-1,50$ & Sangat rendah \\
\hline
\end{tabular}

Dari tiap kategori rasa ingin tahu siswa diambil masing-masing satu anak untuk diwawancarai dan dianalisis lebih lanjut. Jadi, tes digunakan untuk memperoleh data kemampuan literasi statistik siswa, angket digunakan untuk mengetahui karakter rasa ingin tahu (curiosity) sedangkan metode wawancara digunakan untuk mengetahui hal-hal dari siswa yang lebih mendalam (Sugiyono, 2015). Wawancara juga dipakai sebagai penguat dalam memperoleh informasi dari siswa terkait proses pengerjaan soal tes literasi statistik. Keabsahan data diperiksa dengan menggunakan triangulasi teknik, yaitu membandingkan hasil tes literasi statistik dan hasil wawancara dari sumber yang sama pada subjek penelitian. Proses analisis data kualitatif yaitu reduksi data, penyajian data, dan penarikan kesimpulan atau verifikasi (Sugiyono, 2015).

\section{HASIL DAN PEMBAHASAN}

Langkah pertama dalam penelitian ini yaitu menentukan subjek penelitian. Subjek penelitian diperoleh dari hasil angket rasa ingin tahu siswa yang telah diberikan kepada seluruh siswa kelas XII TKJ 1. Hasil angket sejumlah 22 siswa menunjukkan terdapat 1 siswa kategori rasa ingin tahu sangat tinggi, 9 siswa kategori rasa ingin tahu tinggi, 7 siswa kategori rasa ingin tahu sedang, 5 siswa kategori rasa ingin tahu rendah, dan tidak ada siswa yang masuk dalam kategori sangat rendah (rata-rata 1,00 - 1,50). Kemudian hasil angket tersebut didiskusikan dengan guru mata pelajaran matematika untuk pengambilan sampel. Hasilnya diambil empat siswa, dimana masing-masing siswa dalam kategori rasa ingin tahu (curiosity) sangat tinggi, tinggi, sedang, dan rendah. Pengambilan sampel hanya empat siswa karena tidak ada siswa kategori curiosity sangat rendah di kelas XII TKJ 1. Selain itu, siswa yang dipilih juga dengan pertimbangan bahwa siswa tersebut dapat berkomunikasi dengan baik, serta memiliki kemampuan matematika yang setara. Subjek penelitian yang diambil terdapat pada Tabel 3 di bawah ini. 
Tabel 3. Daftar subjek penelitian siswa kelas XII TKJ 1

\begin{tabular}{lll}
\hline Kode Siswa & $\begin{array}{l}\text { Rata-Rata } \\
\text { Skor Curiosity }\end{array}$ & Kategori \\
\hline NS & 4,53 & Sangat tinggi \\
SM & 4,03 & Tinggi \\
AS & 3,43 & Sedang \\
DPS & 2,30 & Rendah \\
\hline
\end{tabular}

Setelah diperoleh subjek penelitian, selanjutnya peneliti memberikan soal tes literasi statistik. Untuk melihat kesesuaian jawaban siswa maka peneliti kemudian melakukan wawancara dengan subjek. Hal ini selain digunakan untuk memeriksa keabsahan data, juga dilakukan agar peneliti dapat mengetahui lebih mendalam mengenai bagaimana siswa mengerjakan. Berikut deskripsi literasi statistik siswa ditinjau dari membaca data.

\section{Kemampuan Membaca Data Terhadap Literasi Statistik}

Diberikan soal di mana siswa harus membaca data, membaca di sini sesuai dua keterampilan yakni pemahaman dan interpretasi (Gal, 2002). Soal menuntut siswa agar dapat merepresentasikan artikel ke dalam tabel, grafik, diagram, atau penyajian bentuk lain. Artikel yang digunakan diambil dari CNN Indonesia dengan judul "Sensus Kendaraan di Indonesia: Lebih dari 133 Juta Unit" (CNN, 2021). Soal artikel tersebut dapat digunakan untuk mengukur kemampuan literasi statistik siswa sesuai indikator-indikator yang diteliti. Berikut contoh jawaban siswa dalam menyelesaikan soal artikel.

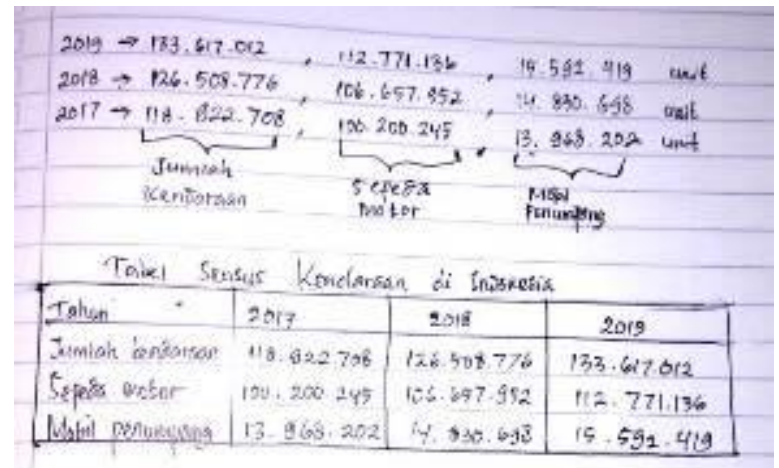

Gambar 1. Siswa membaca artikel menjawab indikator memahami dan menyajikan data

Saat menyelesaikan permasalahan tersebut salah satu siswa kategori curiosity sangat tinggi menjelaskan langkah-langkah bagaimana ia memperoleh jawaban. Siswa tersebut mengatakan bahwa yang pertama kali dia lihat saat membaca soal adalah angka berserta penjelasan dari angka tersebut. 
Lalu sebelum membuat tabel dia mencorat-coret untuk mengurutkan tahun yang tertera pada soal dengan angka-angka yang telah dia tandai. Untuk memperoleh angka yang tepat ia harus memahami isi dari bacaan. Kemudian setelah data tahun, jenis kendaraan, dan jumlah kendaraan serta data lain yang dibutuhkan telah lengkap siswa tersebut baru membuat tabel sebagai salah satu bentuk penyajian data.

Jawaban siswa pada Gambar 1 dan penjelasan menunjukkan bahwa siswa membaca data untuk dapat menjawab soal. Ketika proses menjawab, siswa juga memunculkan indikator literasi statistik berupa memahami data yang kemudian data tersebut siswa representasikan sesuai dengan perintah pada soal. Antara data yang terdapat pada soal dan yang siswa tuliskan sudah sesuai, artinya siswa telah mencapai indikator memahami data melalui membaca persoalan yang diberikan.

Pertanyaan selanjutnya siswa diperintahkan untuk menginterpretasikan artikel ke dalam bentuk penyajian data. Penyajian data pada soal ini memberikan kebebasan untuk siswa memilih. Siswa dapat menyajikannya dalam bentuk tabel, diagram garis, diagram batang, diagram lingkaran, dan seterusnya yang dirasa lebih efektif. Penyajian data merupakan salah satu indikator literasi statistik yang digunakan dalam penelitian ini dan penyajian data sebagai bentuk interpretasi setelah membaca data. Hasil pekerjaan siswa dengan kategori curiosity sangat tinggi, tinggi, dan sedang yang dijadikan sebagai subjek penelitian dapat membaca data-data yang termuat dalam artikel dengan benar. Siswa dapat menuliskan data sesuai dengan bacaan. Perbedaan jawaban dari ketiga siswa tersebut adalah dalam bentuk penyajiannya. Karena dalam soal tidak secara langsung menyebutkan bentuk penyajian data apa yang diminta sehingga ada siswa yang menyajikan hanya dalam bentuk tabel. Namun, ada juga yang melanjutkannya dengan memilih membuat grafik atau diagram batang.

Berdasarkan jawaban yang siswa tulis tersebut kemudian dilakukan wawancara terkait penyajian yang dipilih oleh siswa. Hasil wawancara sebagai berikut.

$P \quad$ : Kenapa kamu hanya menyajikan data dalam bentuk tabel saja?

$S \quad$ : Karena dari soal tulisannya dalam bentuk tabel, grafik, atau diagram bu. Jadi saya pilih salah satunya.

$P \quad:$ Kalau disuruh untuk membuat selain tabel kamu dapat membuat penyajian bentuk lain tidak?

S : Bisa bu.

P : Jenis penyajian apa yang akan kamu buat?

$S \quad$ : Saya akan buat grafik.

$P \quad$ :Baik. Kalau begitu, untuk membuat grafik bagaimana langkah-langkahnya? Coba jelaskan ke bu guru! 
S : :Iya bu. Saya kan sudah membuat tabel. Jadi data-data dari tabelnya saya gunakan untuk membuat grafik. Sumbu-X nya saya buat tahunnya, sumbu-Y untuk angka-angkanya (jumlah kendaraan). Berarti nanti ada tiga diagram yang saya buat.

$P \quad$ : Tiga diagram itu untuk apa saja?

$S \quad$ : Ada jumlah kendaraan seluruhnya, jumlah sepeda motor, dan jumlah mobil. Saya bedakan seperti itu bu.

Pertanyaan serupa pun ditanyakan kepada siswa lain terkait pemilihan bentuk penyajian data. Penyajian data yang dibuat oleh siswa tersebut berupa grafik yang dijadikan satu penyajian

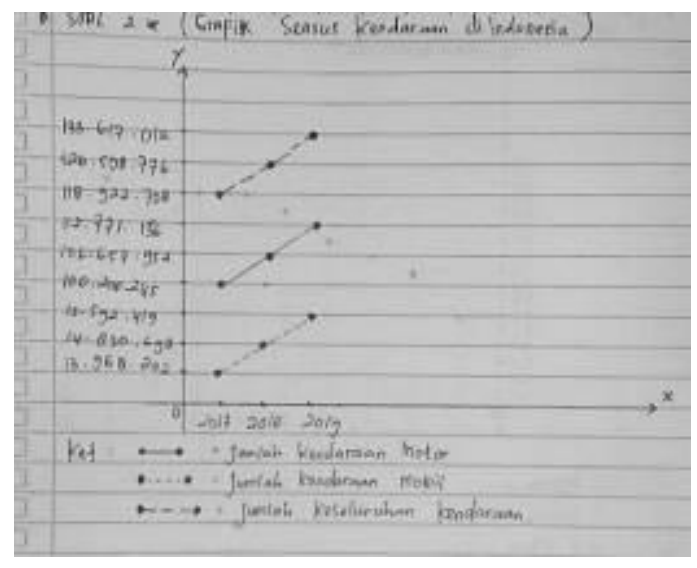

Gambar 2. Siswa menyajikan data bentuk grafik

Berikut hasil wawancara dan jawaban siswa dalam mengerjakan soal artikel.

$P \quad:$ Kenapa grafik yang kamu buat seperti ini?

S : : Saya buat grafiknya jadi satu bu.

$P \quad$ : Coba jelaskan apa yang kamu perhatikan sehingga didapat penyajian data tersebut?

$S \quad$ :Awalnya saya buat tabel, lalu saya buat grafiknya sendiri-sendiri. Saya buat sumbu-X dan $Y$ nya tetap, sumbu-X untuk tahun dan sumbu-Y untuk jumlahnya. Lalu karena saya melihat ada kesamaan, maka grafiknya saya jadikan satu. Untuk membedakan jenis-jenisnya maka jumlah kendaraan motor saya buat garisnya penuh, jumlah kendaraan mobil dibuat putus-putus kecil atau pendek, dan jumlah keseluruhan kendaraan saya buat putus-putusnya lebih panjang.

$P \quad$ : Lalu dari grafik yang kamu buat, menurutmu ada tidak yang masih belum benar?

S : Jarak sumbu-Y nya bu. Jarak yang satu dengan yang lain selisihnya masih salah dan tidak konsisten. Selain itu, saya tidak tahu bu.

Siswa dengan kategori curiosity tinggi dapat menjelaskan apa yang mereka tulis serta dapat menyadari kesalahan yang mereka kerjakan melalui wawancara. Siswa dengan kategori curiosity sedang dapat menyajikan data dengan baik dan sesuai, sedangkan untuk siswa dengan kategori curiosity rendah mereka kesulitan dalam membaca data pada artikel. Hal tersebut dapat dilihat dari 
siswa masih belum benar dalam menuliskan beberapa data. Mereka juga merepresentasikan data tidak sesuai dengan aturan pembuatan diagram, seperti pada gambar di berikut.

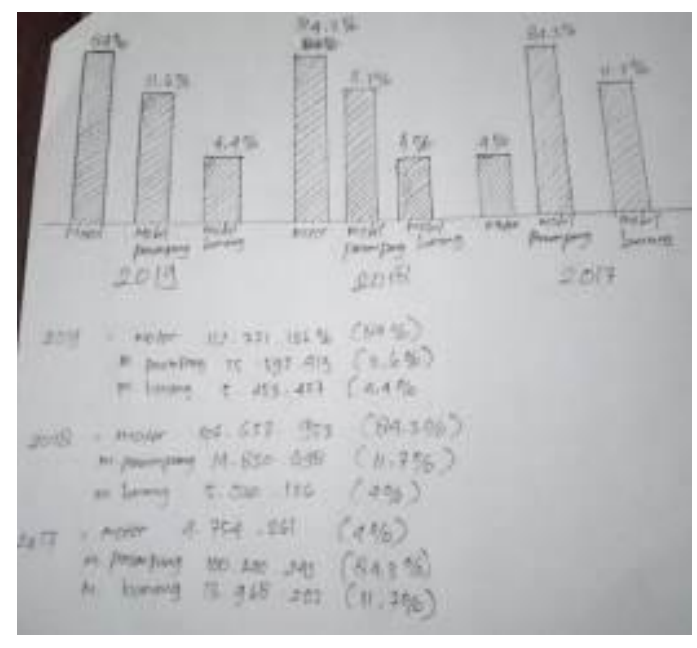

Gambar 3. Kesalahan penyajian data siswa

Ketika dilakukan wawancara dengan siswa kategori curiosity rendah tersebut, siswa masih kesulitan dalam memahami isi artikel. Siswa merasa saat membaca bacaan yang panjang dia tidak dapat berkonsentasi. Siswa merasa bingung dalam mengelompokkan data yang ada dan bingung memilih data-data yang penting. Apalagi karena banyak angka-angka yang muncul dari bacaan. Kemudian saat menyajikan data menjadi bentuk diagram batang siswa belum dapat secara langsung menyadari kesalahannya, terkait dengan tidak ada judul, tidak ada sumbu -X dan sumbu -Y yang ditulis, tidak jelas antara perbedaan batang-batang yang dibuat, dan data-data yang masih salah.

\section{Rasa Ingin Tahu (Curiosity) terhadap Kemampuan Literasi Statistik}

Secara umum, kemampuan literasi statistik berdasarkan curiosity siswa dan dalam membaca data dapat dilihat dari penjelasan berikut.

Tabel 3. Deskripsi kemampuan

literasi statistik berdasarkan curiosity siswa

\begin{tabular}{lll}
\hline No. & Kategori & Deskripsi \\
\hline 1 & Sangat tinggi & Siswa dapat membaca data yaitu memahami dan menginterpretasikan data \\
& dengan baik. Dari membaca data tersebut dapat memunculkan semua \\
& indikator literasi statistik. \\
& Siswa dapat membaca data yaitu memahami dan menginterpretasikan data \\
& dengan baik. Dari membaca data tersebut dapat memunculkan indikator \\
& literasi statistik antara lain memahami data, menghitung data, menyajikan \\
& data, serta menarik kesimpulan dari data. Siswa dengan kategori ini \\
& membutuhkan bantuan dalam indikator menafsirkan sebuah data.
\end{tabular}


KEMAMPUAN MEMBACA DATA DAN RASA INGIN TAHU SISWA TERHADAP ...

Nurokhmi Wahyu Setiani, Amin Suyitno

\begin{tabular}{lll}
\hline No. Kategori & Deskripsi \\
\hline 3 & Sedang & Siswa dapat membaca data yaitu memahami dan menginterpretasikan data \\
& dengan cukup baik. Dari membaca data tersebut dapat memunculkan indikator \\
& literasi statistik antara lain memahami data, menghitung data, menyajikan data \\
& serta menarik kesimpulan dari data. Namun siswa dengan kategori ini \\
& membutuhkan banyak bantuan dalam menafsirkan sebuah data. Kemudian \\
& dalam menghitung dan menyajikan data siswa masih merasa ragu dengan \\
& yang mereka kerjakan. Siswa juga sedikit perlu diluruskan dalam \\
& pengambilan bahasa ketika menyimpulkan data. \\
& Siswa masih kurang dalam membaca data yaitu memahami dan \\
& menginterpretasikan data. Dari membaca data tersebut dapat memunculkan \\
& indikator literasi statistik antara lain memahami data, menghitung data, \\
& menyajikan data serta menarik kesimpulan dari data tetapi belum dalam \\
& jawaban yang dapat dikatakan benar. Siswa tersebut membutuhkan banyak \\
& bantuan dalam menyelesaikan setiap indikator kecuali soal memahami bacaan \\
& tersurat. Kemudian dalam menghitung, menafsirkan, menyajikan data dan \\
& menarik kesimpulan, siswa masih banyak kesalahan.
\end{tabular}

Tes literasi statistik yang diberikan kepada siswa terkait soal tentang berat badan bayi yang dipantau dari lahir hingga usia sepuluh bulan. Dari data yang disajikan dibuat permsalahan yang dapat memunculkan indikator memahami data, menghitung data, menginterpretasikan data, menyajikan data, serta menarik kesimpulan. Hasilnya pada indikator memahami data, semua kategori rasa ingin tahu dapat menyelesaikannya. Hanya siswa dengan kategori rasa ingin tahu yang rendah yang masih merasa sulit jika menyelesaikan soal dengan jawaban yang tidak langsung terlihat atau diketahui dibacaan.

Indikator menghitung data berupa perhitungan mencari mean atau rata-rata dari data yang tersedia serta perhitungan lain yang digunakan untuk membuat kesimpulan. Kategori curiosity sangat tinggi, tinggi, dan sedang mampu menghitung rata-rata dengan benar serta saat ditanya cara memperoleh dan kenapa dapat diperoleh hasil tersebut siswa dapat menjelaskan. Namun, untuk siswa kategori curiosity rendah menyelesaikan dengan benar tetapi jawaban tidak sistematis sehingga pembaca akan kesulitan dalam memahami jawaban siswa tersebut.

Indikator kemampuan literasi statistik yang menjadi permasalahan untuk hampir semua kategori curiosity baik curiosity rendah, sedang, maupun tinggi adalah indikator menafsirkan data. Diketahui berat badan seorang bayi dari lahir (0 bulan) hingga berusia 10 bulan. Lalu siswa diminta 
untuk menafsirkan berat badan bayi saat usia 9 minggu dan saat bayi berusia 12 bulan. Hasil salah satu sampel sebagai berikut.

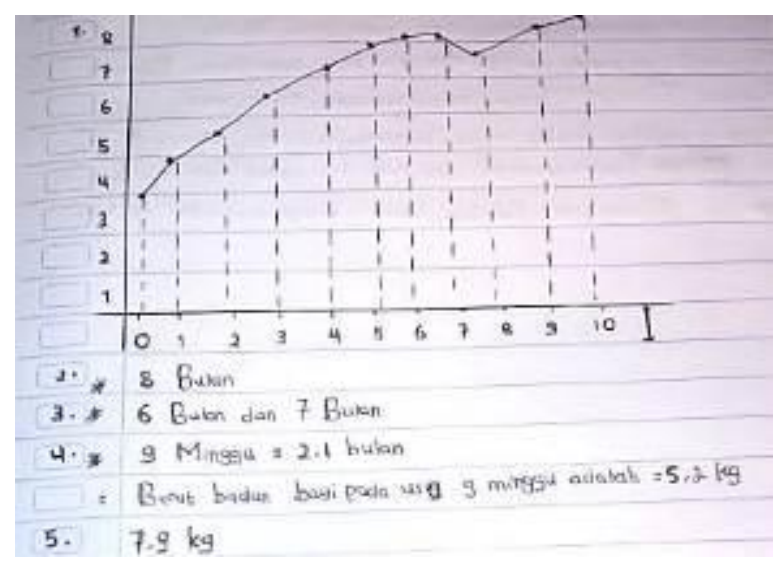

Gambar 4. Menafsirkan data

Soal menafsirkan data terlihat dari Gambar 4 nomor 4. Siswa menjelaskan bahwa 9 minggu diubah menjadi bulan dengan asumsi 1 bulan $=4$ minggu. Namun hasil perhitungan siswa masih salah dengan menjawab 9 minggu = 2,1 bulan. Lalu siswa menafsirkan bahwa 9 minggu berada pada bulan ke-2 dan ke-3, kemudian langsung menentukan hasilnya dengan menjawab 5,2 kg karena 9 minggu itu dapat dianggap berada di bulan ke-2. Begitupun dengan jawaban nomor 5, siswa memperkirakan berat badan bayi pada bulan ke-12 dengan menambahkan $0,1 \mathrm{~kg}$ setiap bulannya. "Bulan ke-9 berat badan bayi 7,6 kg; bulan ke-10 berat badan bayi 7,7 kg; jadi berat badan bayi bulan ke-11 adalah 7,8 kg dan ke-12 adalah 7,9 kg" jelasnya. Berdasarkan jawaban yang ditulis siswa dan penjelasan yang diberikan, dapat disimpulkan bahwa siswa tersebut belum dapat menafsirkan data dengan mengaitkan materi yang dapat digunakan sebagai penafsir yang baik dalam sebuah data.

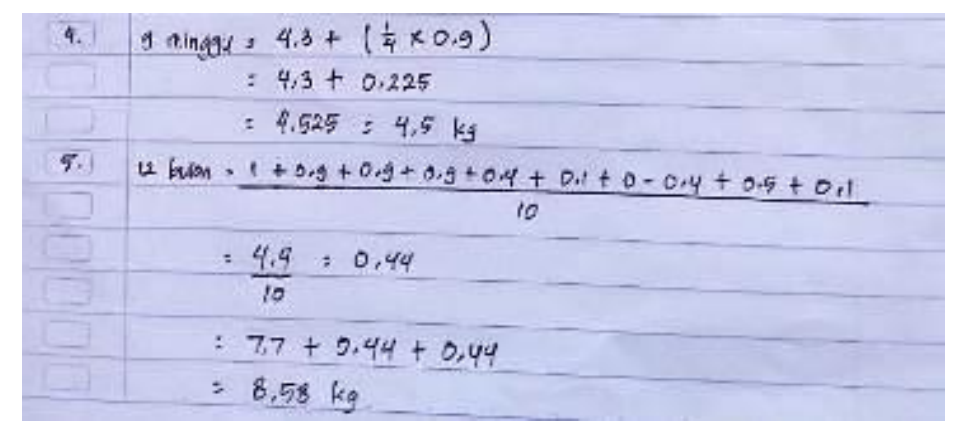

Gambar 5. Jawaban siswa dalam menafsirkan data

Gambar 5 menunjukkan bahwa cara menafsirkan data tiap kategori curiosity siswa berbedabeda. Siswa tersebut memanfaatkan materi rata- rata untuk menfsirkan data sehingga diperoleh hasil seperti pada gambar. Oleh karena itu, dapat disimpulkan bahwa siswa dengan kategori curiosity sangat tinggi langsung dapat menyelesaikan permasalahan dengan indikator menafsirkan data. Siswa dengan kategori curiosity tinggi dapat menjelaskan alasan jawaban yang mereka tulis dalam 
menafsirkan data dan lebih mudah menerima konsep-konsep yang dapat digunakan. Siswa dengan kategori curiosity sedang membutuhkan bantuan dalam menafsirkan data. Terutama dalam memberi petunjuk materi yang dapat digunakan dalam menafsirkan data. Namun untuk kategori curiosity rendah kesulitan dalam menerapkan indikator menafsirkan data meskipun diberikan bantuan untuk menyelesaikan permasalahan.

Indikator keempat dalam penelitian adalah menyajikan data. Menyajikan data dapat dilihat pada jawaban siswa sebelumnya. Siswa kategori curiosity sangat tinggi, tinggi dan sedang dapat menyajikan data dengan baik, bahkan di soal berat badan bayi yang disajikan dalam bentuk diagram garis siswa kategori curiosity rendah dapat membuat penyajian datanya. Saat ditanya kenapa hal tersebut bisa terjadi padahal sama-sama berupa bentuk menyajikan data. Siswa tersebut memberikan alasan bahwa pada soal berat badan bayi data-data sudah diketahui sehingga siswa lebih mudah menyajikannya, sedangkan untuk soal sensus kendaraan siswa terlebih dahulu mencari data-datanya dengan tepat. Kesulitan siswa kategori curiosity rendah juga dalam pemahaman membaca data sehingga pada soal sensus kendaraan penyajian datanya menjadi salah karena pengambilan data yang salah.

Indikator menarik kesimpulan dari data bisa dilakukan oleh semua kategori curiosity. Bedanya pada spesifikasi kalimat yang diambil dan ketepatan bahasa yang digunakan. Siswa kategori curiosity sangat tinggi yang diambil sebagai sampel membuat kesimpulan dengan spesifik dan tepat dalam pengambilan bahasa. Siswa kategori curiosity tinggi menyimpulkan sesuai dengan bacaan pengambilan bahasa perlu diperhatikan. Siswa kategori curiosity sedang yang diambil sebagai sampel membuat kesimpulan dengan baik hanya saja ada kata yang kurang sesuai saat menyimpulkan yaitu kata 'penetapan' yang lebih baik jika diganti dengan kata 'tetap'. Terakhir kategori curiosity rendah. Pada kategori ini siswa dapat menarik kesimpulan seperti jawaban Gambar 6, tetapi akan lebih baik jika kesimpulan dibuat lebih ringkas.

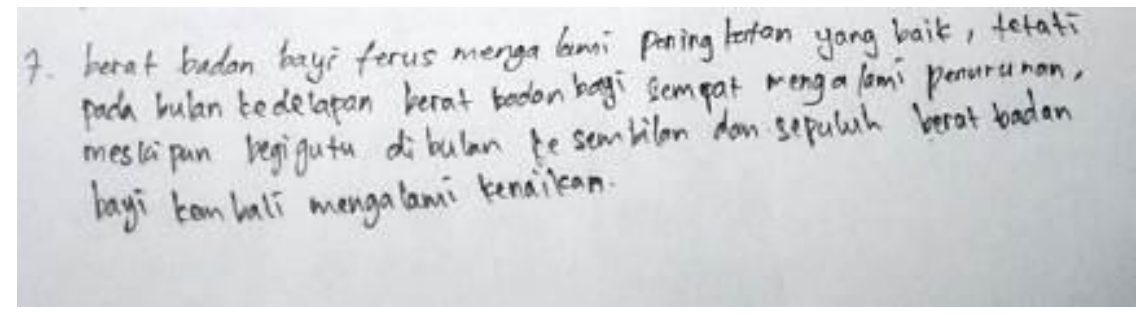

Gambar 6. Menarik kesimpulan dari data 


\section{KESIMPULAN}

Berdasarkan uraian yang telah dijelaskan pada hasil dan pembahasan dapat disimpulkan bahwa kemampuan membaca data dan rasa ingin tahu siswa terhadap kemampuan literasi statistik dapat dilihat dengan memunculkan beberapa indikator literasi statistik. Indikator literasi statistik yang digunakan dalam penelitian adalah memahami data, menghitung data, menafsirkan data, menyajikan data, dan menarik kesimpulan dari data. Dari sampel yang diambil menurut kategori rasa ingin tahu (curiosity) diperoleh bahwa siswa kategori curiosity sangat tinggi dapat memunculkan semua indikator literasi statistik. Siswa kategori curiosity tinggi dan sedang dapat memunculkan indikator literasi statistik antara lain memahami data, menghitung data, menyajikan data, serta menarik kesimpulan dari data. Namun, untuk siswa kategori curiosity sedang membutuhkan bantuan dalam meningkatkan kemampuan mereka terutama dalam menafsirkan data. Terakhir, siswa kategori curiosity rendah masih membutuhkan bantuan hampir diseluruh indikator-indikator literasi statistik.

\section{DAFTAR PUSTAKA}

Amalia, F., Wildani, J., \& Rifa'i, M. (2020). Literasi statistik siswa berdasarkan gaya kognitif field dependent dan field independent. JEMS: Jurnal Edukasi Matematika dan Sains, 8(1), 1-6.

Belecina, R. R., \& Ocampo Jr, J. M. (2016). Mathematical curiosity, epistemological beliefs, and mathematics performance of freshman preservice teachers. Mimbar Pendidikan, 1(1).

Budgett, S., \& Rose, D. (2017). Developing statistical literacy in the final school year. Statistics Education Research Journal, 16(1).

CNN Indonesia. 2021. Sensus Kendaraan di Indonesia: Lebih dari 133 Juta Unit. Tersedia di: https://www.cnnindonesia.com/teknologi/20210203115349-384-601700/sensus-kendaraan-diindonesia-lebih-dari-133-juta-unit [diakses 2-5-2021]

Delmas, R. C. (2002). Statistical literacy, reasoning, and thinking: A commentary. Journal of Statistics Education, 10(2).

Gal, L. (2002). Statistical literacy: Conceptual and instructional issues. Perspectives on adults learning mathematics: Research and practice, 135-150.

Hafiyusholeh, M. (2015). Literasi statistik dan urgensinya bagi siswa. Wahana: Tridarma Perguruan Tinggi, 64(1), 1-8.

Hafiyusholeh, M., Budayasa, I. K., \& Siswono, T. Y. E. (2017, July). Literasi statistik: Siswa SMA dalam membaca, menafsirkan, dan menyimpulkan data. In Prosiding Si Manis (Seminar Nasional Integrasi Matematika Dan Nilai-Nilai Islami) (Vol. 1, No. 1, pp. 79-85). 
Kemendikbud. (2018). Seri pendidikan orang tua: mendidik anak di era digital. Jakarta: Direktorat Pembinaan Pendidikan Keluarga. Tersedia di: https://gln.kemdikbud.go.id/glnsite/wpcontent/uploads/2019/03/3.-SPOT_Mendidik-Anak-di-Era-Digital-REV.pdf [diakses 2-5-2021]

Nishfani, N., Kusmanto, H., \& Akbar, R. O. (2017). Analisis tingkat kemampuan literasi statistik siswa SMA sederajat berdasarkan mutu sekolah. Prosiding Procediamath, 33-47.

Litman, J. A., \& Spielberger, C. D. (2003). Measuring epistemic curiosity and its diversive and specific components. Journal of personality assessment, 80(1), 75-86.

Maryati, I., \& Priatna, N. (2018). Analisis kemampuan literasi statistis siswa Madrasah Tsanawiyah dalam materi statistika. Journal of Medives: Journal of Mathematics Education IKIP Veteran Semarang, 2(2), 205-212.

Sugiyono. 2015. Metode Penelitian Pendidikan (Pendekatan Kuantitatif, Kualitatif, dan R\&D). Bandung : Alfabeta.

Zetriuslita, Z. (2016). Profil sikap ilmiah rasa ingin tahu (curiosity) matematis mahasiswa. Jurnal Ilmu Pendidikan (JIP) STKIP Kusuma Negara Jakarta, 8(1), 41-46. 